Social Work/Maatskaplike Werk Vol 56 No 2; Issue 3

http://socialwork.journals.ac.za/pub

doi:http://dx.doi.org/10.15270/56-2-817

A COLLABORATIVE PARTNERSHIP BETWEEN SCHOOL SOCIAL WORKERS AND EDUCATORS: A VEHICLE TO ADDRESS THE SOCIAL CONTEXTS OF LEARNERS AND QUALITY OF EDUCATION IN SOUTH AFRICA

Edmarie Pretorius

Education is a core indicator of a society's well-being. Globally, it is an established practice to include school social work into the education system. In South Africa, however, it is rarely integrated into the education system. This is a conceptual paper focusing on the social context of school-going children, reflecting on the existing well thought-through frameworks of psychosocial support and care and integrated service delivery of the South African Departments of Education and Social Development, and also questioning why collaboration between the Departments to implement the frameworks in the school environment appears to be a complicated and slow process.

Prof Edmarie Pretorius, Associate Professor in Social Work, School of Human and Community Development, Wits, Johannesburg, South Africa.

Edmarie.Pretorius@wits.ac.za

Keywords: care and support for teaching and learning (CSTL), collaborative partnership, educators, integrated social welfare services, psychosocial challenges, school social workers 


\title{
A COLLABORATIVE PARTNERSHIP BETWEEN SCHOOL SOCIAL WORKERS AND EDUCATORS: A VEHICLE TO ADDRESS THE SOCIAL CONTEXTS OF LEARNERS AND QUALITY OF EDUCATION IN SOUTH AFRICA
}

\section{Edmarie Pretorius}

\author{
Prof Edmarie Pretorius, Associate Professor in Social Work, School of Human and Community \\ Development, Wits, Johannesburg, South Africa.
}

\section{INTRODUCTION}

Education is the foundation of human and socio-economic development and is a core component and indicator of the wellbeing of a society. Worldwide, it is perceived that good-quality education is the only significant stepping stone and way out of poverty (Fleisch, 2008). Globally, school social work is an established practice in approximately 46 developed and developing countries. In many of these countries, social work and education are perceived as complementary professions. In South Africa however, school social work is inconsistently incorporated into the education system.

The developmental and social challenges within the South African context are diverse and complicated. These challenges are influencing the social contexts and wellbeing of all citizens, but children's wellbeing in particular. As is well known, the quality of education in South Africa is questionable. It is of concern that a combination of complicated social challenges like poverty, substance use, violence, HIV and AIDS, and poor education are shaping the social contexts of the majority of South African children and deterring many of them to develop their capabilities and reach their potential in becoming empowered and independent citizens (Pretorius, 2016).

In South Africa, despite a well thought-through framework on care and support in teaching and learning (CSTL)(2010) for learners experiencing barriers to learning in the education sector, and the framework for social welfare services outlining the delivery of integrated developmental social welfare services in the social development sector, collaboration and coordination between these two sectors, the translation and implementation of the frameworks into integrated service delivery in the school environment, appear to be an intricate and gradual process.

I argue that the practice of school social workers is complementary to the practice of educators, the frameworks are available, and there are sufficient opportunities for social workers and educators to collaborate and jointly take responsibility for addressing the social contexts of learners and quality of education in South Africa. The question is why is this not happening?

This is a conceptual paper and the purpose is threefold. Firstly, it provides an overview of the social context in South Africa. Secondly, the conceptual framework on Care and Support for Teaching and Learning (CSTL) (2010) to address barriers to education for children in South Africa and the framework for Integrated Developmental Social Welfare Services in South Africa, are examined. Thirdly, the merit of a collaborative partnership and coordination between the two departments to address the social context of learners and the quality of education in South Africa is highlighted.

\section{THE SOCIAL CONTEXT IN SOUTH AFRICA}

Given the substantially diverse contexts of developed and developing countries, developing social welfare and educational systems suitable to the specific social context and matching the needs of citizens of a particular country, pose challenges. In South Africa, cultural factors contributing to the social context of citizens are diverse and intricate and, in many ways, the effect of socio-economic factors on the social contexts of the majority of South Africans is not contributing to their wellbeing and quality of life. As might be expected, children's social context influences their learning and development, interactions with others, and development of relationships with different systems and in 
turn, these have their own dynamics and complexities and in a reciprocal way, influence the social context of the child (Donald, Lazarus \& Lolwana, 2010).

In South Africa particularly, both colonialism and apartheid influenced the evolution of the design, nature and implementation of education, health and social welfare policies. Legislation and policies implemented by the Nationalist government between 1948 and 1994 were mainly characterised by racial segregation, differentiation and discrimination (Livingstone, 1990; Patel, 2005). Despite twentyfive years of democracy in South Africa, restoring the devastating consequences of a previous system of institutionalised racial segregation on the one hand, and creating a new constitutional democracy that will uphold human and social rights in relation to education and social welfare appropriate for the social contexts of the majority of South African citizens on the other hand, are complicated and challenging. Part of the challenge is to understand the nature and impact of contextual disadvantages, social problems and intrinsic barriers like disabilities and learning difficulties which are major deterrents to the development of children (Pretorius, 2016).

Worldwide, the overwhelming impact of poverty and inequality on education is acknowledged and continuously debated. Poverty and inequality are intricate and multidimensional phenomena and two of the major contextual disadvantages in the South African context. Living in poverty and being exposed to inequality, especially in the remote and rural areas of South Africa, are the reality and shared experience for many South Africans. Children continue being one of the most exposed groups to poverty. In terms of population groups, $85.4 \%$ of children subjected to poverty were African children. According to the 2014/15 living conditions survey, there were 19,7 million children between 0 and 17 years of age in South Africa. Of the children in South Africa, 30.4\% lived in households with no employed adult, $33.7 \%$ with one employed adult and $35.9 \%$ with at least two employed adults (Statistics South Africa, 2018). Of the children, 33.3\% were living below the Food Poverty Line (FPL), $51 \%$ children based on the Lower Bound poverty line (LBPL) and in relation to the Upper Bound Poverty Line (UBPL) seven out of every 10 children, 66.8\%, were living in poverty (Statistics South Africa, 2018; Statistics South Africa, 2019a).

In addition, $85.4 \%$ of African children when compared to children form other populations are most exposed to poverty. Child poverty by geography showed that across all poverty lines $80 \%$ of children in Eastern Cape, Limpopo and KwaZuluNatal live below the UBPL (Statistics South Africa, 2018; Statistics South Africa, 2019b). In poor communities in South Africa, the direct effects of poverty are evident in inadequate shelter, non-existence of or limited basic physical infrastructure, the absence or scarcity of sufficient nutritional food resources, limited or no access to healthcare services, and the lack of adequate safety and protection measures for children. In addition, high rates of unemployment and illiteracy are visible, and poor parental education accompanied with hardly any knowledge about child development exists (Donald, et al., 2010; Fleisch, 2008; Narayan, Chambers, Shah \& Petesch, 2000).

Outlining the indirect effects of poverty is more challenging and because of their psychosocial nature, they are usually related to the direct effects of poverty. Some of the indirect effects are the unintended consequences of migrant working arrangements; larger families with higher number of children, singleparent families (commonly headed by the mother), child-headed households, teenage parenthood, unhealthy parents/caregivers, and insufficient support networks and minimal resources in povertystricken communities.

Research done by Ross (1995) indicated that the stronger the support networks, the more resilient people are in withstanding the tensions produced by poverty. Martha Nussbaum delved deeper into Amartya Sen's capability theory and as explained by Clark (2006) broadened the concept by distinguishing among three types of capabilities namely, innate (genetic potential for normal intelligence), internal with environmental support (adequate nutrition, maternal care and stimulation) and combined (suitable external conditions like opportunity to adequate schooling). It is argued that a balanced combination of the different types of capabilities will most probably allow for healthy cognitive and socio-emotional development of children. 
The triple burden of malnutrition namely, undernutrition, hidden hunger and overweight undermine children's health. The UNICEF (2019) report on Children, Food and Nutrition: Growing well in a changing world, state that globally, two in three children are not provided the minimum recommended diverse diet for healthy growth and development. Unfortunately, in low and middle income countries (LMICs) millions of children's cognitive and socio-emotional development is impaired as a result of malnutrition and deprived care, and they are tricked into a vicious cycle of poor educational achievement, limited access to reasonable income earning opportunities, unemployment or dependence on social grants (in South Africa). As a result, children and young people from the marginalised and poorest communities are carrying the triple burden of malnutrition and the cycle of poverty across generations is perpetuated (Grantham-McGregor, Cheung, Cueto, Glewwe, Richter \& Strupp, 2007; UNICEF, 2019).

Adults' physical and mental health is also affected by poverty-related social conditions. Poor health intensifies poverty as it hinders the potential for income generation and increases the household expenditure. In turn, these affect the children in the family and the complexity of the vicious poverty cycle deepens (Petersen, 2010).

Inequality, which goes hand in hand with poverty, is another major contextual disadvantage in South Africa. Globally, some consider it as part of the modern economic condition required for economic growth and the alleviation of poverty Chaudhuri and Ravallion (2006), and Stiglitz (2012) believe that it can be reduced by the implementation of suitable policies and interventions which are associated with both poverty alleviation and sustainable economic growth. However, countries are unique and their social structures, political environments, cultural diversity, levels of poverty and inequality create fundamentally different playing fields (Habib, 2013).

Division and segregation are the primary characteristics of inequality in society and the author supports the views of Habib (2013:74) who questions whether South Africa will accomplish addressing social problems "...without a sustained reduction in both inequality and poverty".

The combination of the direct and indirect effects of poverty and continuous inequality contribute to different educational, emotional and social developmental risks for children, which often become barriers to learning and achievement and inhibiting social development (Donald et al., 2010). This is confirmed by Fleisch (2008:52) who argues that "Family poverty sets in motion a chain of events that together create intractable impediments in the way of school achievement". In South Africa, the persistence of poverty and inequality promotes the high incidence of and adds to the severity of particular social problems and the so-called marginalised or disadvantaged communities are still experiencing and bearing the brunt of the most prominent social problems more intensely (Donald et al., 2010). Substance use, violence and HIV and AIDS, the more prominent social problems particularly affecting children and shaping their social contexts, will be explored in more detail.

The abuse of a variety of substances is a common practice in developed and developing countries globally, and in South Africa. It is affecting the development of children worldwide. Although South African drug abuse and dependency statistics are disturbingly intermittent, the abuse of drugs (soft or hard) is clearly soaring particularly among children and young people. In 2013, it was stated that one in ten people in South Africa has an addiction problem and Bronwyn Meyers, chief specialist scientist from the alcohol and drug abuse unit of the South African Medical Research Council projected that $11 \%$ of the South African population will suffer from an addiction disorder in their lifetime (Health24, 2013). In South Africa, there are specific kinds of substance abuse that cause clear concerns with reference to the development and education of children and young people.

It is widely known that South Africans consume a lot of alcohol and that South Africa has have among the highest per capita consumption rates in the world that is continuing to rise (World Health Organisation [WHO], 2011). One of the most disturbing legacies of the past is that farm workers, especially those employed on wine farms, received a substantial provision of wine ('dop' system) as part of their payment. This aided chronic abuse of alcohol in families in these communities (Donald $e t$ 
al., 2010). The abuse of alcohol by pregnant women resulted in children being born with fetal alcohol syndrome (FAS), or what is now classified as Fetal Alcohol Spectrum Disorders (FASD) and it has far reaching consequences for the development of children.

Another concern is alcohol abuse among children and youth. Approximately half of the South African population are under 35 years of age and categorised as youth. When under the influence of alcohol, it might lead to unprotected sex resulting in high levels of teenage pregnancy, and the risk to contract sexually transmitted diseases (STDs) and HIV (Jeffreys, 2007; Seggie, 2012).

Apart from children experimenting with and becoming addicted to alcohol, other drugs like 'tik' (methaphetamine) and nayope or whoonga/wunga (a highly addictive mixture of marijuana, heroin and HIV medication) also pose a real challenge and there is an alarming growth in abuse amongst children and youth within the South African context (Plüddermann, Myers \& Parry, 2006). Although these are relatively cheap drugs, the need for higher and more dosages develops quickly and then affordability becomes an issue. Addicts then turn to crime and other antisocial behaviour to accommodate their habit (Health24, 2013). As might be expected, those who abuse alcohol have a greater likelihood of experimenting with other illegal substances.

A combination of factors such as peer pressure, unemployment, poverty, organised crime and gangsterism, easy availability, low cost, and aggressive marketing of drugs like 'tik' appear to contribute to the rapid growing rate of substance use among children and youth (Simbayi, Kalichman, Cain, Cherry, Henda \& Cloete, 2006).

The overwhelming consequences of habitual abuse by children is captured by Donald et al. (2010:217) when claiming that "the child does not [only] suffer progressive physical, neurological and psychological deterioration, but also loses the ability - psychologically, socially, and, often, economically- to break out of the [dependency] cycle."

From an educational and social development perspective, the most worrying aspect of any type of substance use is not only the psychosocial challenges, but also the effects on the developing brain of unborn children, young children and adolescents (DeVane, 1991; Simbayi et al., 2006;). The consequences are evident in school performance and in the long term on the development and general well-being of the citizens in South Africa.

In South Africa, violence is embedded in the social fabric and context of all citizens. Research done by Donson (2008), showed that because of social factors, an especially high-risk group is boys and men within the ages 15 to 29 who are particularly vulnerable to becoming both victims and perpetrators of violence, Krug, Dahlberg, Mercy, Zwi \& Lozano, 2002. Violence has many faces and forms, (Abrahams, Jewkes, Hoffman \& Laubscher, 2004; Burton \& Leoschut, 2012; Krug et al., 2002; Lazarus, Tonsing, Ratele \& van Niekerk, 2009.) and the South African society, both gender violence and child abuse (neglect, sexual, physical or emotional) are major problems and the latter is one of the most disturbing social problems within the South African context. The Optimus research study reported that one in every three learners (35.4\%) had experienced some form of sexual abuse. In addition, $42.2 \%$ experienced one or other form of maltreatment, e.g. sexual, physical, emotional or neglect and $82 \%$ some exposure to victimization, e.g. criminal or family or community violence (UBS Optimus Foundation, 2016).

Bullying, a form of violence is also prevalent in peer groups and institutions such as schools and childcare centres, where relationships are not necessarily intimate, but interpersonal (Richter \& Dawes, 2008; Richter, Dawes \& Higson-Smith, 2004). A study done by the Department of Social Development (2005) confirms that the school environment lends itself as a site for the victimisation of children and young people. Violence in South African schools are widespread. In a research study done by Burton and Leoschut (2012) they found that 22.2\% of high school learners have had been threatened with or experienced assault, robbery and/or sexual assault at the school between August 2011 and August 2012. Continuous abuse poses specific risks to the physical, emotional and social development 
of children. In addition, children are often expose to poyl-victimisation, which results in severe trauma and it has detrimental effects on the development of children (Donald et al., 2010; Leoschut \& Kafaar, 2017).

Understanding collective violence creates context to understanding violence within or around the school context. It is argued by Donald et al (2010:224) that the reasons behind collective violence are often "related to the imbalances and distortions in the power and access to resource of different groups in society, and to basic differences in political viewpoints or goals". Children growing up in oppressed and violent communities and involved in or exposed to political violence, are at risk and might have challenges in their psychological development. Important though to understand that tendencies to violence are more likely to be caused by destructive immediate interactions and experiences in their specific social contexts (Dawes, 1994; Leoschut, 2008; Parker, Dawes \& Farr, 2004).

In South Africa, the prevalence of gang violence, particularly in poverty- stricken communities, is rather perturbing and a challenging problem to solve. The reasons behind this kind of violence are complex, and mainly rooted in economic and identity needs. However, substance use and the role it plays in increased acts of violence is aggravating the situation (Donald et al., 2010; Simbayi et al., 2006). Children and youngsters exposed to violence are likely to find dysfunctional ways of dealing with anxiety, like becoming highly aggressive or using illegal substances which might result in impaired cognitive development, reduced concentration and poor school attendance or school dropout (World Education Forum, 2001).

In 2007, a study by the Centre for the Study of Violence and Reconciliation (CSVR) highlighted the contribution of inequality, poverty, unemployment and marginalisation as well as the vulnerability of young people due to poor child rearing and youth socialisation, as factors contributing to the disturbing levels of violence in South Africa (Parker, 2010).

HIV and AIDS are serious social problems affecting all citizens in South Africa. According to the Human Sciences Research Council (HSRC) (2014) National HIV Prevalence, Incidence and Behavioural 2012 Survey, there were 6.4 million infected South Africans in 2012, which indicates that there are 1.2 million more than in 2008. The Disturbing is the fact that $10.7 \%$ of the respondents indicated having sex before their $15^{\text {th }}$ birthday with higher percentages of males $(16.7 \%)$ and black Africans (11.1\%) reporting this in comparison with their counterparts. Of the respondents, $12.6 \%$ aged 15 years and older reported having more than one partner (Malan, 2014). UNAIDS data (cited in HRSC, 2019) confirms that globally, South Africa has the biggest HIV epidemic. In 2012, the estimate of HIV prevalence among South Africans of all ages was $12.2 \%$ and in 2017 it increased to $14 \%$ with an estimated 7.9 million people living with HIV (PLWHIV) (HRSC, 2019). According to Statistics South Africa (2019c), the mid-year population in South Africa was estimated at 58,78 million. In 2002, the total number of PLWHIV were 4,64 million and in 2019, PLWHIV accounted for approximately 7, 79 million. This implies an increase of 3,33 million more PLWHIV than in 2002 and 0,11million less than in 2017.

According to the HSRC (2019) National HIV Prevalence, Incidence and Behavioural 2017 Survey, the overall incidence among youth aged 15-24 was $1 \%$ which implies 88000 new infections. Of the new infections, $66000(1.51 \%)$ was among females and $22000(0.49 \%)$ was among males, however, the overall incidence among youth aged $15-24$, declined by $17 \%$.

Within the South African context, it is important to understand the patterns of sexual behaviour in relation to cultural influences and HIV risk behaviour. Therefore, it has to be understood from an ecosystemic perspective, as it affects and involves all citizens of South Africa (Wood, 2008).

Challenges experienced by underprivileged households are multiplied by HIV and AIDS and increasing numbers of children and youth are affected. The stigma and discrimination as well as the trauma and grief related to HIV and AIDS-related illnesses can lead to demands and responsibility on school going children and youth to contribute to household income, caring for ill family members, or taking on 
domestic and childcare chores. In turn, this might result in prolonged periods of absenteeism, poor school performance, early school drop-out, lower educational attainment and child-headed households (Giese, Meintjies, Croke \& Chamberlain, 2003; Giese \& Koch, 2008; UNICEF, 2004).

Political, social and cultural factors in South Africa have served to both maintain and extend the pandemic and its consequences, and effectively addressing the causes and consequences is crucial to prevent the pandemic to continue reaping its devastating harvest of human lives (Welch, Clacherty, Donald, Moll \& Winkler, 2008).

Reflecting on the present social context in South Africa, entrenched with poverty and inequality, soaring rates of substance abuse, deep-rooted violence and ruthless ravaging by HIV and AIDS, it is clear that an overwhelming number of children require adequate protection, care and support. The question is what would contribute considerably to provide children and young people with an adequately safe and protected environment in which to learn and develop socially, emotionally and cognitively to become well-adjusted citizens?

Since 1994, the South African government has been grappling with many of these issues. The outcomes were the development and promulgation of policies and procedures to guide interventions and practices in education and social development within the public and private sectors as well as civil society organisations. Both the Departments of Basic Education and Social Development have developed and approved conceptual frameworks to guide professionals on different levels that will be described in more detail.

\section{THE CONCEPTUAL FRAMEWORK FOR CARE AND SUPPORT IN TEACHING AND LEARNING (CSTL) IN SOUTH AFRICA}

Given the social context in South Africa, it is clear that all children need care and support to learn and prosper. However, some children, especially those with limited innate capabilities and those living in poverty- stricken families and communities, are likely to have additional care and support needs. Care and support of learners are critical to achieving educational outcomes and strengthening protective factors to promote their wellbeing and minimising the risk factors that make them vulnerable. The Bill of Rights in the South African Constitution, Act no 108 of 1996 (Republic of South Africa, 1996) dedicates a section to the rights of children, inclusive of their right to education. Despite the development of progressive educational, social and economic policies since democracy in South Africa in 1994, vulnerable children are still experiencing barriers to education which hinder them to achieve their full academic potential.

Care and Support for Teaching and Learning (CSTL) is a SADAC initiative. South Africa was part of a wider regional initiative informed by local and regional processes, i.e. a Baseline Study conducted in 2009/ 2010 in five SADAC Member States (DRC, Mozambique, Swaziland, South Africa and Zambia) by MIET Africa; an in-depth Situation and Response Analysis and a Policy Review for Teaching and Learning in South Africa done by the Department of Basic Education in 2010. (Department of Basic Education and MIET Africa, 2010).

In South Africa a number of interprovincial forums were organised creating opportunity for education officials to participate in the process and develop a common understanding of CSTL's principles, meaning and implications. Considering the uniqueness of the South African context, a customised regional support pack in the form of user-friendly booklets to support the implementation of CSTL in South African schools, was developed (Pretorius, 2016). It is evident that mainstreaming psychosocial support in Basic Education became a prominent focus of the Department of Education (Department of Basic Education and MIET Africa, 2010).

CSTL within the educational environment was not 'new' or 'replacing existing initiatives' to care for and support learners. The purpose was to design an overarching framework that could: 
- Facilitate comprehensive, coordinated and strengthened multi-sectoral efforts to address barriers to teaching and learning for educators and learners.

- Provide guidance to all role-players to situate their work within the framework to create a more streamlined and systematic implementation of care and support for teaching and learning at all levels.

- Realise the education rights of all children and the fundamental goals of the South African education system and the constitutional mandate.

The conceptual framework is flexible and does not prescribe a one-size-fits-all model for all schools. It allows for diversity, seeing that various care and support needs exist in different school communities. The nature and availability of resources and the implementation partners will also differ among school communities (Department of Basic Education and MIET Africa, 2010).

The Conceptual Framework for CSTL is founded on the ecological systems approach which is inclusive of immediate and isolated influences on intrapersonal, interpersonal and societal levels (Donald et al., 2010). It is a holistic approach and comprehensive, as cognizance is taken of protecting and risk factors which are often indicators of vulnerability in children. This particular approach echoes the approach that is articulated in White Paper 6 (2001) which focuses on Special Needs Education and Building an Inclusive Education and Training System. Using this as the underpinning theoretical framework for CSTL, creates awareness and sensitivity to the intrinsic (physical and mental healthrelated problems within the individual child), systematic (inadequate infrastructure, inappropriate methods of teaching and inappropriate teaching material) and societal (poverty, inequality, neglect, violence, substance use and HIV and AIDS) barriers which are hampering vulnerable children from making the most of educational opportunities.

In conjunction with the conceptual framework for CSTL, a policy on Screening, Identification, Assessment and Support (SIAS) was developed, approved and implemented in 2014/15. The SIAS provides a policy framework to standardise procedures of identifying, assessing and providing programmes for learners needing additional support and care with the aim of improving access to quality education for vulnerable and other learners experiencing any barriers to learning (Department of Basic Education, 2014). It is evident that there are progressive procedures and policies in place, however, implementing of frameworks and policies, and collaboration with other stakeholders i.e. the Department of Social Development and non-governmental organisations in the field of child and family care are often lacking and remain challenging.

\section{THE FRAMEWORK FOR SOCIAL WELFARE SERVICES IN SOUTH AFRICA}

The legacy of South Africa's colonial and apartheid history and the political and socio-economic situation in the country in the mid-1990s, informed one of the first policy initiatives promulgated by the new democratic government, the White Paper of Social Welfare 1997. Worldwide, South Africa is one of a few countries that categorically adopted a development approach to social welfare with the acceptance of the White Paper for Social Welfare. The developmental approach to social welfare is strongly rooted in a rights-based approach which implies achieving social justice and equality, as well as empowering those most disadvantaged and marginalised in the society to reclaim quality of life (Patel, 2005). These perspectives are also entrenched in the Constitution of the Republic of South Africa (1996).

The 1997 White Paper for Social Welfare provided guidelines for the transformation of social welfare services. Guidelines such as collective responsibility for social welfare services through collaborative and intersectorial partnerships, acknowledgment of community development as a multisectorial, multidisciplinary and an integrated part of social welfare services, implementation of comprehensive integrated family and community-based strategies and balancing developmental, promotive, preventive, protective and rehabilitative interventions are relevant, considering when arguing for a partnership 
between social work and education (Department of Social Development, 2013; Department of Social Development, 2006, Department of Social Development, 1997).

Considering the 1997 White Paper for Social Welfare, an Integrated Service Delivery Model for Developmental Social Welfare Services was developed by 2006 and provided direction in terms of the nature and scope of services and the levels of intervention (Department of Social Development, 2006). The beneficiaries of services were defined as the poor and vulnerable sectors of the community, and children, youth, families, women and older people were delineated as specific target groups. The range of service providers was defined and their roles and responsibilities were clearly articulated (Department of Social Development, 2006).

Due to a variety of challenges in the changing environment within which social welfare services are rendered, the integration of the service delivery model into practice proofed to be difficult over the past years. Despite some progress in transforming the social welfare sector, practitioners in the sector reflected and realised that ..." further guidance is needed on the implementation of policies and programmes to achieve integrated developmental social welfare services" (Department of Social Development, 2013:8).

The 2006 Integrated Service Delivery Model for Developmental Social Welfare Services was reviewed and it was expected that the new framework will ".... enhance the nature, scope, extent and level of integrated social welfare services that social service practitioners should be delivering" (Department of Social Development, 2013:9). The revised framework emphasises comprehensive, integrated and rights-based social welfare services and collaborative partnerships among public and private sectors, training and research institutions and civil society.

The Framework for Developmental Social Welfare Services (2013:17) explicitly states that the role and responsibilities of the National Department of Basic Education are to:

- "Develop and implement policies, programmes and strategies to guide the delivery of developmental social welfare services in the education sector.

- Put mechanisms in place that acknowledges social service professionals/practitioners as crucial in learner support programmes.

- Develop a referral system to link vulnerable children with the necessary resources.

- Commit resources to the delivery of social welfare services that seek to promote learners/students' well-being in the different provinces."

In relation to the above points, the Department of Education (DoE) has made some progress. The CSTL (Department of Basic Education and MIET Africa, 2010), Integrated School Health Policy (ISHP) (Health and Basic Education, 2012), SIAS (Department of Basic Education, 2014) and a Draft Strategy on Psychosocial Support for Learners in South African Schools (Department of Basic Education, 2016) have been developed and partially implemented.

It appears that across the nine provinces in South Africa, social workers are involved in different numbers, ways and levels to render psychosocial services to learners in school settings. Some might be employed in special schools under the Public Service Act no 103 of 1994 (Republic of South Africa, 1994), others are employed in terms of the Employment of Educators Act no 76 of 1998 (Republic of South Africa 1998), are often referred to as 'socio-pedagogues' or 'senior education specialists' Voster (cited in Vergottini, 2018:44) and not school social workers. Apart from these categories, some social workers are appointed in mainstream and special schools in posts subsidised by school governing bodies (SGBs).

In the Western Cape, the Department of Education employs 70 school social workers to render social welfare services in schools across the province. In Eastern Cape, Free State, Gauteng, KwaZuluNatal, Limpopo, Mpumalanga, North West and Northern Cape, the Department of Education have a small number of school social workers ranging from two to 46, in their employ (Vergottini, 2018). In 
Gauteng the Department of Social Development allocates social workers to schools, however, there are a number of logistical challenges that these social workers have to deal with to render services to school going children. Some progress has been made and the Gauteng Departments of Social Development and Education have signed a memorandum of understanding in September 2018 regarding social work services in schools. A joint planning session on Social Work Services to Schools took place on 13-15 March 2019, and a project team was formed to plan how the two departments will craft the way forward.

Despite the fact that children and youth are demarcated as target groups within the scope of social welfare services in South Africa, and schools and learners are reasonably easily accessible, there are very few school social workers employed by either the Departments of Education or Social Development to render adequate school social work services to learners in school settings.

The comprehensive report on the national review on the implementation of the 1997 White Paper for Social Welfare by the social services sector in South Africa between September 2013 and March 2016 showed that in critical areas like child protection, violence prevention, substance abuse, trauma counselling and mental health care the demand for social welfare services far exceed the existing levels of social service delivery (Department of Social Development, 2016).

In addition, there is no consistency in the model of school social work service delivery, and discrepancies in the approaches followed when rendering school social work services in the nine provinces in South Africa. According to the Department of Social Development (2016: 339) the review revealed that there is ..." confusion about the different roles of different departments", ..."as well as differences in approach, philosophy, working styles, methods and traditions..." (Department of Social Development, 2016: 334) when working in partnerships.

The above confirms the urgent need for the Departments of Education and Social Development to:

- Further develop and enhance existing structures recognising the contributions of school social work professionals/practitioners as vital members of the multidisciplinary team in learner support programmes, and

- Ensure that sufficient resources are earmarked to facilitate the delivery of social welfare services that foster learners' well-being across the nine provinces in South Africa.

In many areas, the philosophy and aims of both education and developmental social welfare and social development concur and mutually strengthen each other - both have a deep concern with the maximum protection and development of children, fostering growth of all individuals to accomplish their potential, and ensuring that the physical, emotional, educational and social conditions of the child allow for optimum development (Livingstone, 1990). The question is why, notwithstanding well thoughtthrough frameworks in both the Departments of Education and Social Development, do departments in the public sector struggle to collaborate and work together in a coordinated manner in achieving the philosophy and aims of both by incorporating social workers in schools?

Undoubtedly, deliberating about strategic partnerships among different sectors is fairly common, but finding ways in translating and implementing important principles and approaches, i.e. collaboration into practice, appears to be highly challenging. The potential worth of a collaborative partnership between departments of Education and Social Development will be explored.

\section{THE MERIT OF A COLLABORATIVE PARTNERSHIP AND COORDINATION BETWEEN THE DEPARTMENT OF EDUCATION AND DEPARTMENT OF SOCIAL DEVELOPMENT}

Globally, in the past 40 years, collaborative initiatives among different sectors have become more prominent in addressing the social needs and development in communities and society as a whole. In South Africa, the collective responsibility of collaborative and strategic partnerships among different sectors (public, civil society organisations and private) and between departments or business units 
within the public and/or private sectors, is accentuated by the National Development Plan. Crosssectorial partnerships is a multidisciplinary field underpinned by collaboration theory (Gray \& Wood, 1991); governance theory from the public policy literature (Wettenhall, 2003; O'Brien, Goetz, Scholte \& Williams, 2000); institutional theory (Lounsbury, Ventresca \& Hirsch, 2003) and complexity theory (White, 2001). This is an evolving multidisciplinary field that is shaped by changing social contexts, public expectations, and complex social issues. These continuously influence the formation of collaborative and strategic partnerships.

Collaboration is one of the universally endorsed approaches to strategic partnerships. Many scholarly definitions of collaboration exist, however, appropriate for this discussion is Sink's (1998:1188) definition explaining collaboration as "a process by which organizations [departments within a sector] with a stake in a problem seek a mutually determined solution [pursuing] objectives they could not achieve working alone". Sharing a transformational intention to strengthen systemic capacity when employing common resources, is another consideration and for both partners, achieving mutual benefits, appears to be central to collaboration (Gray, 1989; Pinney, 1999; Waddell \& Brown, 1997; Wood \& Gray, 1991).

In both the conceptual frameworks for CSTL and Social Welfare Services, it is clearly articulated that different sectors have a collective responsibility in terms of the provision of equitable services and particularly in meeting the educational and social needs and rights of South African children. Given South Africa's social context and the expectations from citizens about obtaining quality education, their rights to accessing and receiving equitable healthcare, and appropriate developmental social welfare services, it is important to realise that the Departments of Education and Social Development are actually strategic partners in improving the social context of children and the quality of education in South Africa.

Obviously, there is only merit in collaborative partnerships when both partners have complimentary objectives; roles and responsibilities are explicit; trust is present in the relationship; the partnership is likely to yield mutual benefits for all involved; regular and open communication exists and power and control in terms of decision-making are equally shared. Why then, despite clearly formulated frameworks, do collaboration, cooperation, coordination, integration and translation of these frameworks into practice remain a challenge within the South African context?

Collaboration is complex (Department of Social Development, 2016; Fosler, 2002; Gazley \& Brundey, 2007) and requires less than authoritative coordination and more than tacit cooperation. New relationships cause blurring boundaries between sectors or departments. When working in a multidisciplinary field, consciously or unconsciously, tensions around trust, control, power and identity develop in the partnership process and the relationship between the two departments and/or members of the different departments might be inevitably tense due to the confusing, or contested roles and functions performed by each department. In addition, the level of political interference cannot be underestimated and adds to the complexity.

The challenge is to find the balance and ensure that each partner does what they can do best and in the long run, that the learners benefit from the interventions of both partners. Teachers' expertise is the education of learners, and social workers' expertise lies in assessing the person in the environment, examining capabilities and potential, as well as challenges. Linking the person with available and appropriate resources in the community, and with the necessary trust and support, the person is likely to take ownership, and be empowered to overcome difficulties and adapt adequately to society.

Collaborative partnerships between different sectors have opportunities and perils as highlighted by research (Ashman, 2001; Gazley \& Brundey, 2007; Selsky \& Parker, 2005). Some of their findings might provide clarity on the merits of and challenges with a partnership between the Departments of Education and Social Development, and will consequently be explored. Firstly, the differences in 'cultures' of the different departments in the public sector have to be considered. Their contexts are influenced by different social, political, cultural and economic factors. Entering into a partnership 
might provoke concerns about loss of autonomy, questions about accountability, uncertainty about assessment, monitoring and evaluation, and apprehension to spend limited institutional time and resources on a collaborative partnership. Secondly, issues of building sufficient trust, a critical contributor to successful partnerships, ensuring shared control and preventing coercive power from one partner in collaborative partnerships, remain potential perils and require mindfulness from both parties involved.

Thirdly, it is imperative that the rationale for collaboration has to be clear and partners should have compatible objectives (Ashman, 2001). This implies that the focus should be explicit and parties have to understand the importance of collaboration in achieving the common goal, i.e. care and support to improve the social contexts of learners and enabling them in achieving their potential and reaching the educational outcomes. Fourthly, open communication and agendas are the life blood of a partnership. This will contribute to building trust, cohesion and productivity among parties involved. Lastly, valuing and respecting the diversity in thinking of the experts from different fields with specialised knowledge and skills involved in the partnership, is likely to contribute to finding more suitable solutions to the problems (Selsky \& Parker, 2005).

When collaborating in the true sense of the word, there will not be unhealthy competition but the promotion of shared goals and integrated service delivery to the benefit of the children in South Africa. As stated by Department of Education and MIET South Africa (2010:40), "Well-defined partnerships, with clear articulated parameters, expectations, roles and responsibilities are a prerequisite for the realization of the care and support objectives [in schools]". A collaborative partnership between the Department of Education and Department of Social Development in implementing school social work might become the vehicle to address both the social and educational challenges South Africa is facing.

The context in which many learners live, is riddled with poverty, dysfunctional families, inequality, poly-victimisation, violence, high prevalence and easy availability of alcohol and substances and HIV and AIDS. Therefore, they are at very high risk to develop emotional and behavioural problems that affect their optimal functioning within the school system. The emotional stressor experienced by learners are demonstrated in their behaviour in the school setting. As a result on the one hand it constrains teachers to solely focus on the learners' educational needs and challenges, and on the other, it hampers and prevents learners to achieve their educational potential (Anderson-Butcher \& Ashton, 2004).

Consequently, the psychosocial challenges experienced by learners should be addressed first to enable teachers and learners to achieve the expected educational outcomes in terms of the curriculum and the learner's potential. It is evident that schools and the Department of Education cannot do this on their own. Therefore, the school social worker should become the first and preferred partner to collaborate and develop an interdependent relationship with.

According to the National Committee on School Social Work Education and Practice (NACOSSWEP) (2015), school social work is a specialised field within social work, a practice-based profession, that occurs within educational institutions. Services rendered by the school social worker address social, emotional and behavioural barriers to learning experienced by learners at an educational institution from an ecological, systems theory and strengths-based perspective. These services are aimed at supporting learners, parents/guardians and families, educators (teachers), and the school as a community. In addition, the school social worker ensures that learning and development take place through early identification of psychosocial barriers and appropriate intervention. Adequate assessments can be made and learners in need of protection, remedial assistance, rehabilitation and restoration can be referred to organisations specialising in the particular services (Department of Social Development, 2006).

The primary scope of services within the school setting is promotive, preventive and supportive. Through promotive, preventative, supportive and developmental service delivery, Care and Support for Teaching and Learning (CSTL) are enhanced by providing all learners the opportunity to access 
applicable resources to enable them to reach their full potential. Developmental social work services can be delivered to children, parents, teachers and the broader community where the school is located, using knowledge and skills on micro, mezzo and macro levels of practice (Openshaw, 2008), and using the different methods of social work practice applicable within the school setting. School social work forms an integral part of the education context and contributes towards the academic performance and overall wellbeing of learners within a healthy, safe and secure school environment. Finally, school social work makes a unique contribution because the school social worker brings the family (home), the school and the community perspectives to the multidisciplinary team process, which facilitates better understanding of the social context of the learner (NACOSSWEP, 2015).

Collaboration with the school social worker is the starting point, however, different models of collaboration applicable in the school system exist. Collaboration with other members of the multidisciplinary team, e.g. the psychologist, speech therapist, nurses is often also required. This is referred to as "intraorganizational collaboration" (Anderson-Butcher \& Ashton, 2004:40). Lawson \& Barkdull (cited in Anderson-Butcher \& Ashton, 2004:41) also refers to "Interagency collaboration" which means the collaboration between two or more independent organisations or departments developing formal agreements to work together achieving a common goal, e.g. an organisation that specialises in mental health care, or providing food to learners and their families.

In addition, there is "interprofessional collaboration" Lawson \& Barkdull (cited in Anderson-Butcher \& Ashton, 2004:42). This model implies one or more people from different professions or organisations collaborating to deliver integrated and coordinated services to the learners and their families without duplicating service delivery. The focus is no longer "child-centered and school-focused" (AndersonButcher \& Ashton, 2004:43), however, inclusive of the family and community where the learners comes from or the school is located in. For example, a fundraising organisation bring their expertise to the table to assist with fundraising for the school to provide all learners with school uniforms or stationery. The result is that the learners are likely to arrive at school with more confidence and prepared to learn (Anderson-Butcher \& Ashton,2004). Another model of collaboration often overlooked and challenging is "family-centered collaboration" Lawson \& Barkdull (cited in AndersonButcher \& Ashton, 2004:43). This model of collaboration implies that the voices of learners and parents/guardians are acknowledged and heard and they become expert partners with professionals and the school to decide what type of services is needed. The choice of the school and teachers is to view the parents as not interested in, apathetic and unsupportive of the child's learning, or they can embrace an attitude of "whatever it takes" (Anderson-Butcher \& Ashton, 2004:44) to involve the family and learner to participate in planning the learner's future.

Lastly, "community collaboration" (Anderson-Butcher \& Ashton, 2004:45) focuses on valuing diversity and inclusivity of all the different stakeholders in the school and the community to engage, work together support and learn from each other. This requires social planning, which is a problemsolving process for addressing challenges within communities, e.g. organised gang free community partnerships to reduce and prevent gangs in communities. The different models of collaboration are interrelated and in the long run if implemented, it will "...provide ways in which schools can gain support for themselves and for the [learners] and their families with whom they work at school (Anderson-Butcher \& Ashton, 2004:48).

According to the South African Schools Act no 84 of 1996 (Republic of South Africa, 1996), it is compulsory for children from seven to 15 years of age or completion of Grade 9, to attend school. Therefore, schools are good sites for care and support, and ideal spaces for implementing different models of collaboration to deliver integrated services on different tiers but with a focus on promotion, prevention and early detection of psychosocial challenges experienced by learners. The school social worker can be leading and facilitating the collaboration process in different ways. The school social worker's skill set allows for him/her to coordinate, network, collaborate, lead, communicate and connect, encourage, empower and most importantly, advocate and represents the learner and 
families/guardians “...voices he or she serves" (Anderson-Butcher \& Ashton, 2004:49; Pretorius, 2014).

Getting the collaborative partnership between different partners and especially between the departments Education and Social Development off the ground, is a slow process and it might be useful if both partners reflect on what drives and what stifles the energy to cooperation and move forward. Once the root causes of the restraining factors have been identified and are understood, the exploration of alternative solutions for those restraining factors (over which the departments have control), might enhance the process of collaboration to be more productive and focused on the common goal, the learner.

\section{CONCLUSIONS}

Colonialism and apartheid created a legacy of injustice and inequality in terms of the social welfare and education systems in South Africa. The social context of South Africa's children is cemented with poverty, inequality and a variety of social problems of which malnutrition, substance use, violence and HIV and AIDS are the most prominent aspects affecting their development and limiting them to achieve their potential. As a result, a vast number of children in South Africa require one or other form of assistance and support.

Since 1994, South Africa has a democratic government that conceptualised, developed and promulgated progressive legislation, policies and procedures especially in the areas of education, social welfare and healthcare. However, the translation and implementation of these policies remain challenging. Almost 25 years into democracy, collaborative partnerships emerged as the approach to use in an attempt to overcome the challenges with successful implementation of processes, programmes and/or interventions. A collaborative partnership is a useful, but also a complex strategy that requires a number of principles to be adhered to in ensuring it to be successful. The Departments of Education and Social Development both have progressive conceptual frameworks that can be implemented in improving the social context of learners and providing care and support for learners and educators in education.

Many of the social problems is evident in learners behaviour in the school environment and schools are perfect sites for school social workers as collaborative partners of educators and other professionals within the school setting to create continuous and systemic interventions in addressing the challenges learners and educators are experiencing on different levels by incorporating different systems and resources. The regular incorporation of school social work in the education system, where considerable additional support is needed, will facilitate the implementation of both frameworks in a collaborative and integrated manner and contribute to the development of learners to become well-adjusted and productive citizens in South Africa. The question remains, why is this not happening?

\section{REFERENCES}

ABRAHAMS, N., JEWKES, R., HOFFMAN, M. \& LAUBSCHER, R. 2004. Sexual violence against intimate partners in Cape Town: Prevalence and risk factors reported by men. Bulletin of the World Health Organisation, 82(5): 330-337.

ANDERSON-BUTCHER, D. \& ASHTON, D. 2004. Innovative models of collaboration to serve children, youths, families and communities. Children and Schools, 26(1): 39-53.

ASHMAN, D. 2001. Civil society collaboration with business: Bringing empowerment back in. World Development, 29(7): 1097-1113.

BURTON, P. \& LEOSCHUT, L. 2012. School Violence in South Africa: Results of the 2012 National School Violence Study. Centre for Justice and Crime Prevention Monograph Series No 12, Cape Town, South Africa. 
CHAUgDHURI, S. \& RAVALLION, M. 2006. Partially awakened giants: Uneven growth in China and India. In: WINTERS, L.A. \& YUSUF, S (eds). Dancing with giants: China, India and the global economy. Washington: World Bank.

CLARK, D.A. 2006. Capability approach. In: CLARK, D.A. (ed). The elgar companion to development studies. Cheltenham, UK: Edward Elgar.

DAWES, A. 1994. The emotional impact of political violence. In: DAWES, A \& DONALD, D. (eds). Childhood and adversity: Psychological perspectives from South African research. Cape Town: David Philip.

DEPARTMENT OF BASIC EDUCATION AND MIET AFRICA. 2010. National Support Pack. MIET Africa.

DEPARTMENT OF BASIC EDUCATION. 2012. Integrated School Health Policy (ISHP). Pretoria, South Africa: Government Printer.

DEPARTMENT OF BASIC EDUCATION. 2014. Policy on Screening, Identification Assessment and Support (SIAS). Pretoria, South Africa: Government Printer.

DEPARTMENT OF BASIC EDUCATION. 2016. Draft Strategy on Psychosocial Support for Learners in South African Schools. Unpublished, Pretoria, South Africa.

DEPARTMENT OF SOCIAL DEVELOPMENT. 1997. White Paper for Social Welfare. Pretoria, South Africa: Government Printer.

DEPARTMENT OF SOCIAL DEVELOPMENT. 2005. Policy framework for orphans and other children made vulnerable by HIV and AIDS, South Africa: Building a caring society together. Pretoria, South Africa: Government Printer.

DEPARTMENT OF SOCIAL DEVELOPMENT. 2006. Integrated Service Delivery Model: Towards improved social services. Pretoria, South Africa: Government Printer.

DEPARTMENT OF SOCIAL DEVELOPMENT. 2013. Framework for Social Welfare Services. [Online] Available: www.dsd.gov.za. [Accessed:01/2016].

DEPARTMENT OF SOCIAL DEVELOPMENT. 2016. Comprehensive Report on the Review of the White Paper for Social Welfare, 1997. Pretoria, South Africa: Government Printer.

DEVANE, L. 1991. Pharmacokinetic correlates of fetal drug exposure. National Institute on Drug Abuse Research Monograph, 14: 18-36.

DONALD, D., LAZARUS, S., \& LOLWANA, P. (eds). 2010. Educational psychology in social context. Ecosystemic applications in Southern Africa $\left(4^{\text {th }}\right.$ ed). Cape Town: Oxford University Press.

DONSON, H. 2008. A profile of fatal injuries in South Africa 2007. Cape Town: Medical Research Council/UNISA Crime, Violence and Injury Lead Programme.

FLEISCH, B. 2008. Primary education in crisis. Why South African school children underachieve in reading and mathematics. Cape Town, South Africa: Juta \& Co.

FOSLER, R.S. 2002. Working better together: How government, business, and nonprofit organizations can achieve public purposes through cross-sector collaboration, alliances, and partnerships. Washington, DC: Independent Sector.

GAZLEY, B. \& BRUNDEY, J. L. 2007. The purpose (and perils) of government-nonprofit partnership. Nonprofit and Voluntary Sector Quarterly, 36(3): 389-415.

GIESE, S. \& $\mathrm{KOCH}$, R. 2008. A review of education policy to address the active and passive exclusion of learners affected by HIV and AIDS from attending or participating in schooling., Cape Town: Alliance for Children's Entitlement to Social Security. 
GIESE, S., MEINTJIES, H., CROKE, R. \& CHAMBERLAIN, R. 2003. Health and social services to address the needs of orphans and other vulnerable children in the context of HIV/AIDS: Research report and recommendations. Report submitted to the National Departments of Health and Social Development by the Children's Institute, University of Cape Town.

GRANTHAM-MCGREGOR, S., CHEUNG, Y.B., CUETO, S., GLEWWE, P., RICHTER, L., \& STRUPP, B. 2007. Developmental potential in the first 5 years for children in developing countries. The Lancet, 369: 60-70.

GRAY, B. 1989. Collaborating: Finding common ground for multiparty problems. San Francisco: Jossey-Bass.

GRAY, B. \& WOOD, D.J. 1991. Collaborative alliances: Moving from practice to theory. Journal of Applied Behavioral Science, 27(1): 3-22.

HABIB, A. (2013). South Africa's suspended revolution hopes and prospects. Johannesburg, South Africa: Wits University Press.

HEALTH24. 2013. $\mathbf{1}$ in $\mathbf{1 0}$ in $\mathbf{S A}$ has addiction problem. [Online] Available: http://www.health24.com/Lifestyle/Street-drugs/News/Dagga-alcohol-top-SA-drug. [Accessed: 02/2016].

HEALTH AND BASIC EDUCATION. 2012. Integrated School Health Policy. Pretoria, South Africa: Government Printer.

HUMAN SCIENCE RESEARCH COUNCIL (HSRC). 2014. South Africa's National HIV Prevalence, Incidence, Behaviour and Communication 2012 Survey. Cape Town, South Africa: HSRC Press.

HUMAN SCIENCE RESEARCH COUNCIL (HSRC). 2019. South Africa's National HIV Prevalence, Incidence, Behaviour and Communication 2017 Survey. Cape Town, South Africa: HSRC Press.

JEFFREYS, B. 2007. Alcohol disease 'hits young hard' [Online] Available: http://news.bbc.co.uk/2/hi/7092347.stm [Accessed: 02/16].

KRUG, E., DAHLBERG, L., MERCY, J., ZWI, A. \& LOZANO, R. (eds). 2002. World report on violence and health. Geneva: World Health Organisation.

LAZARUS, S., TONSING, S., RATELE, K. \& VAN NIEKERK, A. 2009. An exploratory study into the risk and protection factors to male interpersonal violence. Medical Research Council Tygerberg, Cape Town.

LEOSCHUT, L. 2008. School violence: What makes learners vulnerable? Centre for Justice and Crime Prevention, Issue Paper 7: 1-12.

LEOSCHUT, L \& KAFAAR, Z. 2017.The frequency and predictors of poly-victimisation of South African children and the role of schools in its prevention. Psychology, Health and Medicine, 22(S1): 81-93.

LIVINGSTONE, B.J. 1990. School Social Work Practice. In: MCKENDRICK, B. W. (ed). Social work in action. Pretoria, South Africa: HAUM.

LOUNSBURY, M., VENTRESCA, M. \& HIRSCH, P. 2003. Social movements, field frames and institutional emergence: A cultural-political perspective on U.S. recycling. Socio-Economic Review, 1: 71-104.

MALAN, M. 2014. SA has the highest number of new HIV infections worldwide. Mail \& Guardian, 01 April, 2014. [Online]. Available: http://mg.co.za/article/2014-04-01-sa-holds-highest-number-ofnew-hiv-infections-worldwide. [Accessed: 01/2016]. 
NATIONAL COMMITTEE FOR SCHOOL SOCIAL WORK EDUCATION AND PRACTICE (NACOSSWEP). 2015. Application for School Social work as a specialization area: A National Association of Social Workers South Africa's submission to the South African Council of Social Service Professions (SACSSP). 15 December 2015.

NARAYAN, D., CHAMBERS, R., SHAH, M.K. \& PETESCH, P. 2000. Voices of the poor crying out. New York: Oxford University Press.

O'BRIEN, J., GOETZ, A.M., SCHOLTE, J.A., \& WILLIAMS, M. 2000. Contesting global governance: Multilateral economic institutions and global social movements. Cambridge, MA: Cambridge University Press.

OPENSHAW, L. 2008. Social work in schools. Principles and practice. New York, NY: The Guilford Press.

PARKER, F. 2010. Why South Africa is so violent. Mail \& Guardian, 09 November 2010. [Online]. Available: http://mg.co.za/article/2010-11-09-why-sa-is-so-violent [Accessed: 01/2016].

PARKER, Z., DAWES, A., \& FARR, V. 2004. Interpersonal youth violence prevention. In: SUFFLA, $S$ \& VAN NIEKERK, A. (eds) and DUNCAN, N. (Consulting ed). Crime, violence and injury prevention in South Africa: Developments and challenges. Tygerberg: MRC-UNISA Crime, Violence and Injury Lead Programme.

PATEL, L. 2005. Social welfare and social development in South Africa. Cape Town, South Africa: Oxford University Press.

PETERSEN, I. 2010. At the heart of development: an introduction to mental health promotion and the prevention of mental disorders in scarce-resource contexts. In: PETERSEN, I., BHANA, A., FLISCHER, A.J., SWARTZ, L \& RICHTER, L. (eds). Promoting mental health in scarce resource contexts. Emerging evidence and practice. Cape Town, South Africa: HSRC Press.

PINNEY, C. 1999. Business and civil society organizations: toward a new partnership. In: L. REGELBRUGGE (ed). Promoting corporate citizenship. Washington, DC: CIVICUS.

PLÜDDERmanN, A., MYERS, B., \& PARRY, C. 2006. Alcohol and Drug Abuse Module. SA Healthinfo: Alcohol and Drug Abuse Research Unit, Medical Research Council, ${ }^{\text {st }}$ November 2006. [Online] Available: http://www.sahealthinfo.org/admodule/methaphetamine.htm [Accessed: 02/2016].

PRETORIUS, E. 2014. The social worker as a collaborative partner in the educational context. In: MOONSAMY, S \& KATHARD, H. (eds). Speech-language therapy in a school context. Principles and practices. Pretoria, South Africa: Van Schaik Publishers.

PRETORIUS, E. 2016. Challenges in pre-tertiary education in South Africa: Is school social work part of the solution? School Social Work Journal, 40(2): 61-78.

REPUBLIC OF SOUTH AFRICA. 1994. Public Service Act no 103 of 1994. Government Gazette. Pretoria, South Africa: Government Printer.

REPUBLIC OF SOUTH AFRICA. 1996. The Constitution of the Republic of South Africa Act 108 of 1996. Government Gazette. Pretoria, South Africa: Government Printer.

REPUBLIC OF SOUTH AFRICA. 1996. South African Schools Act no 84 of 1996. Government Gazette. Pretoria, South Africa: Government Printer.

REPUBLIC OF SOUTH AFRICA. 1998. Employment of Educators Act no 76 of 1998. Government Gazette. Pretoria, South Africa: Government Printer.

RICHTER, L., \& DAWES, A. 2008. Child abuse in South Africa: Rights and wrongs. Child Abuse Review, 17(2): 79-93. 
RICHTER, L., DAWES, A., \& HIGSON-SMITH, C. (eds). 2004. Sexual abuse of young children in Southern Africa. Cape Town: HSCR Press.

ROSS, F. 1995. Umntu ngomntu ngabanye abantu: The support networks of black families in Southern Africa. Pretoria: HSRC Press.

SEGGIE, J. 2012. Alcohol and South Africa's youth. South African Medical Journal, 102(7). [Online] Available: http://www.samj.org.za/index.php/samj/printerfriendly/6003/4278. [Accessed: $\underline{02 / 2016] .}$.

SELSKY, J.W. \& PARKER, B. 2005. Cross-sector partnerships to address social issues: Challenges to theory and practice. Journal of Management, 31(6), 849-873.

SiMBAYI, L., KAliCHMAN., S., CAIN, D., CHERRY, C., HENDA, N. \& CLOETE, A. 2006. Methaphetamine use and sexual risks for HIV infection in Cape Town, South Africa. Journal of Substance Use, 11: 291-300.

SINK, D.W. 1998. Interorganizational collaboration. In: SHAFRITZ J. M. (ed). The international encyclopedia of public policy and administration. Boulder, CO: Westview.

STATISTICS SOUTH AFRICA. 2018. Men, Women and Children. Findings of the Living Conditions Survey 2014/15. Report number 03-10-02. Pretoria, South Africa.

STATISTICS SOUTH AFRICA. 2019a. National poverty lines. Statistical Release P0310.1. Pretoria, South Africa.

STATISTICS SOUTH AFRICA. 2019b. Inequality trends in South Africa. A multidimensional diagnostic of inequality. Report number 03-10-19., South Africa: Pretoria.

STATISTICS SOUTH AFRICA. 2019c. Mid-year Population Estimate 2019. Statistical Release P0302. South Africa: Pretoria.

STIGLITZ, J. 2012. The price of inequality. New York: Allen Lane.

UBS OPTIMUS FOUNDATION. 2016. Optimus Study South Africa: Sexual victimization of children in South Africa Final Report of the Optimus Foundation Study: South Africa. Switzerland: Zurich.

UNICEF 2004. HIV and AIDS and Education. The role of education in the protection, care and support of orphans and vulnerable children living in a world with HIV and AIDS. UNAIDS inter Agency Task Team on Education. New York: UNICEF.

UNICEF. 2019. The state of the world's children 2019. Chidren, food and nutrition: Growing well in a changing world. New York: UNICEF.

VERGOTTINI, E.M. 2018. Towards the establishment of practice standards for South African school social work. A mixed methods study with special reference to the Free State Province. North West University, Potchefstroom, South Africa. (PhD thesis)

WADDELL, S. \& BROWN, L.D. 1997. Fostering intersectoral partnering: A guide to promote cooperation among government, business and civil society actors. IDR Reports, 13(3): 1-26.

WELCH, T., CLACHERTY, G., DONALD, D., MOLL, I. \& WINKLER, G. 2008. Being a teacher in the context of the HIV/AIDS pandemic. Pretoria: Higher Education South Africa.

WETTENHALL, R. 2003. The rhetoric and reality of public-private partnerships. Public Organization Review, 3: 77-107.

WHITE, L. 2001. Effective governance through complexity thinking and management science. Systems Research and Behavioral Science, 18(3): 241-257. 
WOOD, L. 2008. Sociocultural factors. In: WOOD, L. (ed). Dealing with HIV/AIDS in the classroom. Cape Town: Juta.

WOOD, D.J. \& GRAY, B. 1991. Towards a comprehensive theory of collaboration. Journal of Applied Behavioral Science, 27(2): 139-162.

WORLD EDUCATION FORUM. 2001. Education for All 2000 Assessment: School Health and Nutrition. Dakar, Senegal, 26-28 April, UNESCO, France.

WORLD HEALTH ORGANISATION (WHO). 2011. Global Status Report on Alcohol and Health 2011.

[Online]

http://www.who.int/substance_abuse/publications/global_alcohol_report/en/index.html. 02/2016].
Available:

[Accessed: 